L. XIN ${ }^{1,2,3}$, Ch. ZETAO ${ }^{1,2}$, Zh. YUNPENG ${ }^{1,2}$, X. JIALI ${ }^{1,2}$, W. SHUICAI ${ }^{3}$, and Z. YANJUN ${ }^{3}$

\title{
STRESS STATE EVALUATION BY AN IMPROVED SUPPORT VECTOR MACHINE
}

\author{
Received March 26, 2014
}

Effective methods of evaluation of the psychological pressure can detect and assess realtime stress states, warning people to pay necessary attention to their health. This study is focused on the stress assessment issue using an improved support vector machine (SVM) algorithm on the base of surface electromyographic signals. After the samples were clustered, the cluster results were given to the loss function of the SVM to screen training samples. With the imbalance amongst the training samples after screening, a weight was given to the loss function to reduce the prediction tendentiousness of the classifier and, therefore, to decrease the error of the training sample and make up for the influence of the unbalanced samples. This improved the algorithm, increased the classification accuracy from $73.79 \%$ to $81.38 \%$, and reduced the running time from 1973.1 to 540.2 sec. Experimental results show that this algorithm can help to effectively avoid the influence of individual differences on a stress appraisal effect and to reduce the computational complexity during the training phase of the classifier.

Keywords: surface electromyographic signals, stress state evaluation, support vector machine, clustering, weight.

\section{INTRODUCTION}

Psychological or mental stress is a psychosomatic tension state that tends to be manifested in various types of psychological and physiological reactions when a person becomes aware that the confronting environment is important but rather difficult to deal with [1]. Moderate stress can make subjects to produce positive energy and may be changed into a motive power to improve the work efficiency. However, stress that exceeds the person's limit may cause negative effects or even significantly affect one's normal life [2]. The recognition of the cause of stress before it becomes chronic is a key step in managing it.

Methods that can be used for stress appraisal in the psychology usually require a significant response of and positive cooperation with the subject. The

\footnotetext{
${ }^{1}$ Institute of Biomedical Engineering, Yanshan University, Qinghuangdao, China.

${ }^{2}$ Measurement Technology and Instrumentation Key Laboratory of the Hebei Province, Qinghuangdao, China.

${ }^{3}$ College of Life Science and Bio-Engineering, Beijing University of Technology, Beijing, China.

Correspondence should be addressed to L.Xin (e-mail:yddylixin@ysu.edu.cn), or Z. Yanjun (e-mail: yjzeng@bjut.edu.cn).
}

application of stress appraisal will be wider and beneficial for the research on stress and health if it can operate without self-evaluation.

In engineering, affective computing is used to assess the intensity of stress. Stress states of drivers were evaluated based on the speech and physiological parameters [3, 4]. A traditional game, Tetris, could be used as the stress source, and this allowed researchers to collect respiratory and electromyographic (EMG) signals in a group of 129 subjects; this study reached an average recognition rate of above $80 \%$ by using linear discriminant analysis and $r$ to analyse the results [5]. In other study [6], a stress detection method based on physiological measurements of 22 subjects was proposed. Each subject in this study was exposed to a protocol containing four stressors and six rest periods. A simple wireless device was designed [7] for detection and daily evaluate of routine stress automatically and permanently.

In the next study [8], nine call centre employees as examined subjects were asked to wear a skin conductance sensor on their wrists for a week at work, to record the stress levels for each call. Individual differences were addressed by either modifying the loss function of a support vector machine (SVM) 
to adapt to the varying priors or by placing more significance on training samples from the most similar people in terms of the skin conductance lability to automatically recognise classes of the stressful/nonstressful calls [8].

Physiological measurements can detect stress with a minimal discomfort for the subjects and are useful in reflecting emotions [9]. In our study, we selected four stress sources to stimulate the participants. One hundred forty-four groups of EMG signals were collected from each of the 16 subjects. The existing SVM algorithm was improved to solve the stress evaluation problem with increased classification accuracy and to reduce the classifier's processing time. The feasibility of the experimental scheme and the algorithm were proven by using real data.

\section{METHODS}

Improved SVM. A kernel-based machine, SVM, learns a family of methods used to accurately classify both linearly separable and linearly inseparable data [10]. The SVM has been used in numerous machine learning fields, such as classification, regression estimation, and kernel principal component analysis, because it is capable of providing a good generalisation capacity.

Contrastive analysis showed that different participants have different perception degrees of the same stimulus, and that the same participant often produces different responses to different stress sources at the same time. Actual verification showed that solving the diversity problem between samples is difficult even after normalisation. Making predictions for a single participant causes a certain amount of interference and affects on the classifier performance if all sample information is included in the training set. Furthermore, too many training samples increase the computational complexity and influence the classification accuracy. Therefore, making a targeted selection for the training set is obviously necessary.

Filtration of the training sets results in an imbalance between positive and negative samples. Thus, different weights are given to positive and negative samples, and sample information is added to the loss function to weaken this imbalance.

Optimised Algorithm. The overall flow chart of the algorithm is shown in Fig. 1. The improved SVM algorithm can reduce the amount of training samples by selecting training sets and addressing stress evaluation. Thus, only the most beneficial message for the classifier's model building is put in. Otherwise, the adjustment of the weight of positive and negative samples can amend the imbalance in training samples. Therefore, this algorithm can reduce the computation complexity at the training stage and, in a parallel manner, to improve the classification accuracy.

Selection of the Training Samples. This algorithm aimed at seeking the correlation degree between each training sample and the testing sample by clustering. The correlation factor that describes the correlation degree to the loss function of the SVM's is then provided to combine the classifier with the practical issue and make it different from the classifier that fits all of the common classification problems. The algorithm specifically improves the evaluation accuracy.

The standard expression of the SVM is

$$
\min _{\mathrm{w}} \frac{1}{2}\|\mathrm{w}\|^{2}+\frac{\mathrm{C}}{\mathrm{n}}\left(\sum_{\mathrm{i} \in\{\mathrm{y}=+1\}}^{\mathrm{n}_{+}} \varepsilon_{\mathrm{i}}+\sum_{\mathrm{j} \in\{\mathrm{y}=-1\}}^{\mathrm{n}_{-}} \varepsilon_{\mathrm{j}}\right)
$$

s.t. $y_{i}\left(w^{T} x_{i}\right) \geq 1-$ and $\varepsilon_{i} \geq i=1,2, \ldots n$

where $\mathrm{C}$ is the misclassification cost, and ... is the slack variable for the sample....

The SVM's loss function can be expressed as

loss function $=\frac{\mathrm{C}}{\mathrm{n}} \sum_{\mathrm{i}=\mathrm{j}}^{\mathrm{n}}$.

The improved algorithm's loss function expression is the following:

loss function $=\frac{\mathrm{C}}{\mathrm{n}}\left(\mathrm{v}_{\mathrm{i}} \sum_{\mathrm{i}=1}^{\mathrm{n}} \varepsilon_{\mathrm{i}}\right)$

where $\mathrm{n}$ is the number of training samples, and $v_{\mathrm{i}}$ defines the similarity between sample $\mathrm{i}$ and the testing sample for classification, to solve the sample differences problem.

Each group of the data centre section of $10 \mathrm{sec}$ is truncated, and $\mathrm{K}=2$ is set to divide all samples into two categories based on the k-means clustering algorithm, and $v_{i}=1$ is set when the training sample belongs to the same category as the testing one. Otherwise, a weak correlation is considered to exist between the training and testing samples, and $v_{i}=0$ is set.

The leave-one-out method is used for classification evaluation.

Classification Weight. An imbalance occurs between the almost equal original positive and negative samples are used after making selection to the training samples with the improved SVM algorithm. This 


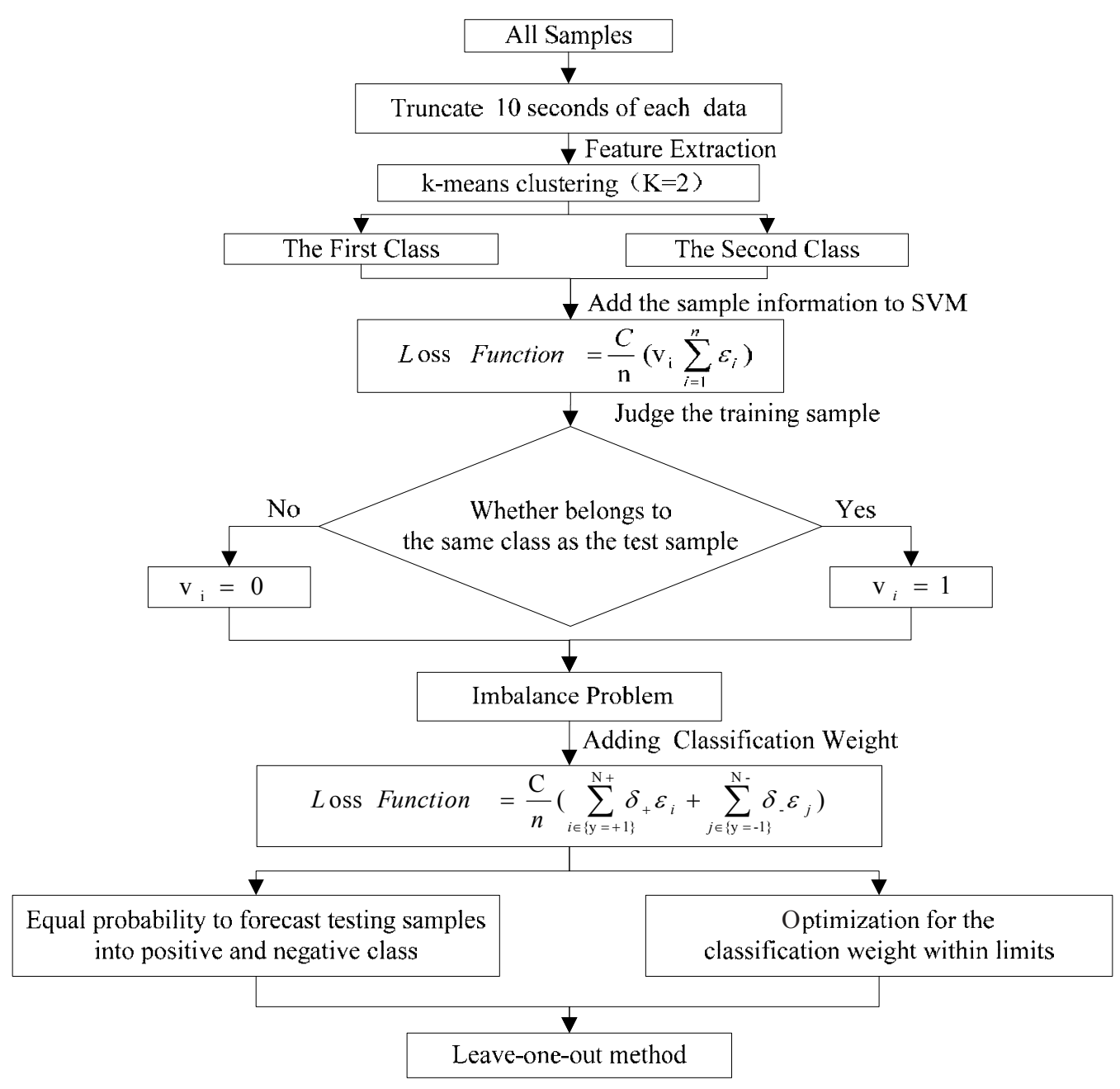

F i g. 1. Flow chart of an improved SVM algorithm.

P и с. 1. Блок-схема вдосконаленого алгоритму SVM.

imbalance leads to the error sum of the positive class smaller than that of the negative class. An example of this imbalance is when the amount of positive samples is significantly smaller than that of negative samples. Thus, a larger penalty weight exists with respect to the negative class, causing the separation plane to move toward the positive class.

The weights of the positive are set to $\delta_{-}$, and negative samples are set to $\delta_{-}$, to solve the data imbalance problem. This problem is addressed by changing the classified weight in the loss function. The loss function of the improved SVM is expressed as

loss function $=\frac{\mathrm{C}}{\mathrm{n}}\left(\sum_{\mathrm{i} \in\{\mathrm{y}=+1\}}^{\mathrm{N}_{+}} \delta_{+} \varepsilon_{\mathrm{i}}+\sum_{\mathrm{j} \in\{\mathrm{y}=-1\}}^{\mathrm{N}_{-}} \delta_{+} ;\right.$
Let $\left\{\left(X_{i}, y_{i}\right)\right\}_{i=1}^{n}$ be the training set, where $X_{i}$ represents the feature vector of the sample $i$, and $y_{i}$ is the class label, where $y_{i}=\{-1,1\}$. Let the class priors of this set be

$$
P_{+}=\frac{\# y=1}{n}=\frac{n_{+}}{n} \text { and } P_{-}=\frac{n_{-}}{n}
$$

Two ways have been tried to improve the classified weight. One way is to set $\frac{\delta_{+}}{\delta_{-}}=\frac{P_{-}}{P_{+}}$; then, the probabilities that the classifier groups divide the samples into positive and negative classes tend to be similar to each other. 
The other way is to optimise the weights.

The error sums of the positive and negative classes are better to be equal to the balance of positive and negative errors [11], as follows:

$$
\sum_{\mathrm{y}_{\mathrm{i}}=1} \delta_{+}^{2} \varepsilon_{\mathrm{i}}^{2}=\sum_{\mathrm{y}_{\mathrm{i}}=-1} \delta_{-}^{2}
$$

The from the formula is uncertain; thus, determining the exact relationship between $\delta_{+}$and $\delta$ is difficult. However, an approximation relationship can be obtained by assuming that the mathematical expectations of the positive and negative class errors are the same:

$$
\mathrm{N}_{+} \delta_{+}^{2}=\mathrm{N}_{-} \delta_{-}^{2}
$$

where $N_{+}$is the number of positive samples, and $N_{\text {- }}$ is the number of negative samples; $\delta_{-}$is set to be 1 for calculation convenience; thus, $\delta_{+}$tends to be $\sqrt{\mathrm{N}_{-} / 1}$. A more compromise way adopted is to avoid an over adjustment. Optimisation for $\delta_{+}$is made between 1 and $\sqrt{N_{-} / N_{+}}$by consulting an $\operatorname{SVM}(\mathrm{c}, \mathrm{g})$ optimisation approach, which is a method to optimize the SVM parameters.

Experiment Design. Subjects. The selected subjects were 16 students ( 8 men and 8 women), students and postgraduate students of the Yanshan University. All of the subjects were healthy and right-handed. The EMG signals under conditions of stress stimulation were collected using the method described below.

Questionnaire. Before data collection, the subjects were asked to fill in a questionnaire, to evaluate their recent psychological states. Distributing of the questionnaires is a convenient method for identification of the one's real situation and evaluation of the effect of the experiment. If the recent physiological state was out of the requirements, we should change the volunteer. The subjects were also asked to fill another questionnaire PSTRI (Psychosomatic Tension/related Inventory) after the data collection, to evaluate their present psychological state and, therefore, to test whether the experiment raised the stress level of the subjects. The results of application of these questionnaires were treated as references to the stress level. The questionnaires were used for data analysis.

Data collection. An MP150 multi-channel physiological recorder (Biopac Company, ..........) was used to record surface EMG (sEMG) signals from the subjects (Fig. 2). The experiment was conducted within four consecutive days.

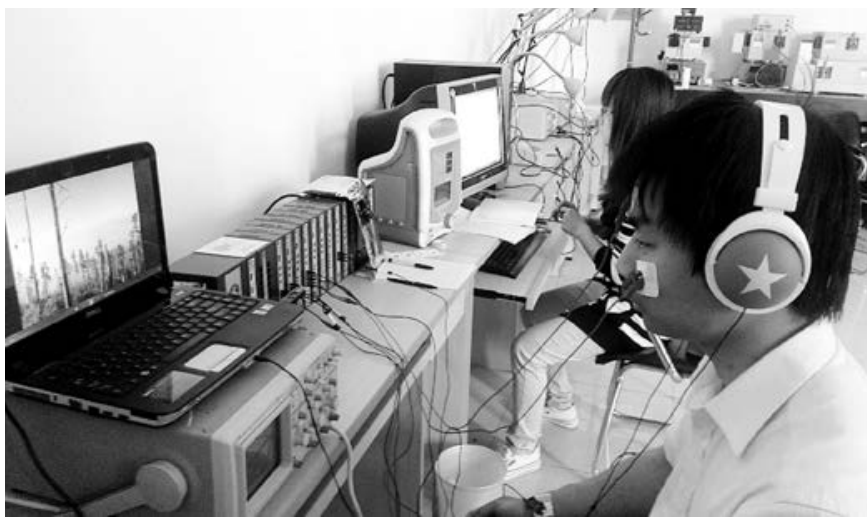

F i g. 2. EMG measurements with an MP150 multi-channel physiological recorder.

Р и с. 2. Вимірювання електроміограм із використанням багатоканального реєстратора фізіологічних даних МР150.

Day 1. Studies showed that office noises even of a low intensity cause emotional stress to the workers $[12,13]$. To obtain a better effect of stimulation, five of the top 10 intranquil voices from a survey result (Prof. T. Cox, Salford University, Great Britain) were chosen to be the experimental environment of stress stimulation. The subjects were asked to remember a large group of numbers within a limited time and against a noisy background. The stimulation mode is shown in Table 1.

\section{T a b l e 1. Experimental process of number memorisation}

Т а б л и ц я 1. Експериментальний процес

\begin{tabular}{|c|c|c|}
\hline Stimulus & Duration & Function \\
\hline $\begin{array}{l}\text { Light music }+ \\
\text { scenery pictures }\end{array}$ & $2 \mathrm{~min}$ & $\begin{array}{l}\text { Place subjects in a state } \\
\text { of relaxation }\end{array}$ \\
\hline Slide (first time) & $50 \mathrm{sec}$ & $\begin{array}{l}\text { Place subjects in a state } \\
\text { of stress }\end{array}$ \\
\hline Slide(second time) & $35 \mathrm{sec}$ & $\begin{array}{l}\text { Place subjects in a state } \\
\text { of stress }\end{array}$ \\
\hline Slide(third time) & $15 \mathrm{sec}$ & $\begin{array}{l}\text { Place subjects in a state } \\
\text { of stress }\end{array}$ \\
\hline $\begin{array}{l}\text { Light music }+ \\
\text { scenery pictures }\end{array}$ & $1 \mathrm{~min}$ & $\begin{array}{l}\text { Place subjects in a state } \\
\text { of relaxation }\end{array}$ \\
\hline
\end{tabular}
запам'ятовування чисел

Day 2. College students were facing a growing pressure of employment with the growing numbers of undergraduates and the increasingly fierce social competition. A video describing the employment outlook of university students was used as the stimulus to arouse potential stress among the participants. The process is presented in detail in Table 2. 


\section{T a b l e 2. Experimental process of video stimulation}

Т а б л и ц я 2. Експериментальний процес відеостимуляції

\begin{tabular}{lll}
\hline Video material & Duration & Function \\
\hline $\begin{array}{l}\text { Light music }+ \\
\text { scenery pictures }\end{array}$ & $2 \mathrm{~min}$ & $\begin{array}{l}\text { Place subjects in a state of } \\
\text { relaxation } \\
\text { Employment }\end{array}$ \\
$\begin{array}{l}\text { outlook video } \\
\text { Light music }+\end{array}$ & $15 \mathrm{~min}$ & $\begin{array}{l}\text { Place subjects in a state of } \\
\text { stress }\end{array}$ \\
scenery pictures & & $\begin{array}{l}\text { Place subjects in a state of } \\
\text { relaxation }\end{array}$ \\
\hline
\end{tabular}

Day 3. A word memorisation task was conducted as the experiment. Participants were asked to remember a group of relatively difficult English words within a 3-min-long interval. The sound of a stopwatch was played within the last minute, to give the participants a sense of urgency. At the same time, all the words were designed in negative meanings, to produce a certain psychological hint and place the subjects in a negative emotional state, producing an environment conducive to stress [14]. The detailed processes are shown in Table 3.

T a b l e 3. Experimental process of word memorisation

T а б л и ц я 3. Експериментальний процес запам'ятовування слів

\begin{tabular}{lll}
\hline Stimulus & Duration & Function \\
\hline $\begin{array}{l}\text { Light music }+ \\
\text { scenery pictures }\end{array}$ & $2 \mathrm{~min}$ & $\begin{array}{l}\text { Place subjects in a state of } \\
\text { relaxation }\end{array}$ \\
Word & $3 \mathrm{~min}$ & $\begin{array}{l}\text { Place subjects in a state of } \\
\text { stress }\end{array}$ \\
$\begin{array}{l}\text { memorisation } \\
\text { Light music }+\end{array}$ & $1 \mathrm{~min}$ & $\begin{array}{l}\text { Place subjects in a state of } \\
\text { relaxation }\end{array}$ \\
\hline
\end{tabular}

Day 4. Adopting the stress stimulation method applied in the Augsburg University (Germany), we used the traditional game Tetris as the stress source. The game difficulty (falling speed of the blocks) was increased during the experiment to arouse higher stress among the subjects. The participants were given only 5 min to relax before the game. The data of the subjects under the highest speed were collected to determine the stress level.

\section{RESULTS}

Data Pre-Processing. One hundred forty-four groups of the data, including 72 groups of the stress data and 72 groups of the non-stress data, were obtained after the processing. Finally, the data were saved and labelled.

Surface EMG is characterized by weak signals, strong noises within a low-frequency range, and strong randomicity due of the influence of numerous factors. Thus, the first step was to denoise the collected signals. The db9 wavelet was used to conduct wavelet decomposition of the noisy sEMG. Finally, 28 statistical characteristics were obtained by making feature extraction from the noise-cancelled sEMG signal.

Stress Evaluation. The improved algorithm showed a better classification performance, compared with the ordinary (c, g) optimisation SVM and (c, g) optimisation using the genetic algorithm SVM [15].

The 10-sec-long data were intercepted to determine the effect of the data length on the classification accuracy. Specific results are reported in Tables 4 and 5 .

\section{T a b l e 4. Truncated 20-sec data}

Т а б л и ц я 4. Скорочені 20-секундні дані

\begin{tabular}{|c|c|c|c|}
\hline Algorithm & Accuracy of the training sets & Accuracy of the testing sets & Time \\
\hline Optimised $(\mathrm{c}, \mathrm{g})$ by grid search & $97.29 \%$ & $70.34 \%$ & $895.3 \mathrm{sec}$ \\
\hline $\begin{array}{l}\text { SVM based on genetic algorithm } \\
\text { optimisation }\end{array}$ & $98.27 \%$ & $68.28 \%$ & $\begin{array}{l}2026.5 \\
\sec \end{array}$ \\
\hline Improved SVM by screening training samples & $98.09 \%$ & $77.93 \%$ & $569.3 \mathrm{sec}$ \\
\hline $\begin{array}{l}\text { Improved SVM by screening training samples and } \\
\text { searching the SVM weight }\end{array}$ & $98.03 \%$ & $79.31 \%$ & $541.3 \mathrm{sec}$ \\
\hline
\end{tabular}


T a b l e 5. Truncated 10-sec data

Т а б л и ц я 5. Скорочені 10-секундні дані

\begin{tabular}{|c|c|c|c|}
\hline Algorithm & Accuracy of the training sets & Accuracy of the testing sets & Time \\
\hline Optimised (c, g) by grid search & $99.76 \%$ & $73.79 \%$ & $702.4 \mathrm{sec}$ \\
\hline $\begin{array}{l}\text { SVM based on genetic algorithm } \\
\text { optimisation }\end{array}$ & $99.12 \%$ & $77.93 \%$ & $1973.1 \mathrm{sec}$ \\
\hline Improved SVM by screening training samples & $98.65 \%$ & $79.31 \%$ & $545.2 \mathrm{sec}$ \\
\hline $\begin{array}{l}\text { Improved SVM by screening training samples } \\
\text { and searching the SVM weight }\end{array}$ & $98.92 \%$ & $81.38 \%$ & $540.2 \mathrm{sec}$ \\
\hline
\end{tabular}

\section{DISCUSSION}

Experimental results showed that this program can arouse the subjects' stress state to a certain degree. Changes in the stress state were reflected in sEMG signals. Different stressors were selected to stimulate the participants within four consecutive days. Thus, the "adaptability" problem was avoided, and the feasibility of the laboratory-induced stress project was improved. Subsequently, the collected data can be used to evaluate and analyse the stress state.

According to the research findings in [7], the SVM model was optimised directly at the individual difference problem. The testing samples included the skin conductance data of all subjects in one day or the skin conductance data of one subject for four days. The rest of the samples were included in the training set for the prediction. The imbalance between samples was amended by making $\mathrm{S}_{+}=\overline{\mathrm{P}}_{+} /$and $\mathrm{S}_{-}=\overline{\mathrm{P}} /$, where and are the corresponding weights of the two groups of samples, and are the class priors of the different samples. This algorithm joined the information of the testing set into the building of SVM model whereas it is impossible to know the proportion of stressful/ non-stressful events for the subjects in the actual stress evaluation work. Obviously, this approach has a limitation because the values of and are unknown.

For this limitation, two approaches were proposed to modify the class weights that only relied on the known sample information rather than introduce the testing set details. The classification model based on this theory was built. This model can be used for stress evaluation in the real environment. In addition, only one sample was selected for the test each time, and the samples associated with it were selected for training. The cycle was repeated until every sample was assessed as the testing set. That is a classification model for each sample that conformed to its own characteristics was built for each cycle. Using the real leave-one-out method to validate the theoretical results was more aligned with the research purposes.

The SVM optimisation based on the genetic algorithm had the highest training accuracy but the lowest testing accuracy, which indicated that the classifier came from an overfitting problem.

The classification time showed that the SVM optimisation based on the genetic algorithm expended the amount of time and memory overhead. The SVM optimisation based on normal $(\mathrm{c}, \mathrm{g})$ searching required a long training time. By contrast, the improved algorithm greatly reduced the computation complexity in the training stage and, therefore, shortened the classifier's training time. This advantage is even more significant when the training sample size is large.

Comparative analysis showed that selection of the improved algorithm for the training samples avoided the interference of the redundant information and reduced the classifier's computation complexity in the training phase, thereby improving the overall classification accuracy, while decreasing the training time. The classified accuracy was generally improved when the truncated data length was equal to $10 \mathrm{sec}$.

Our study aimed to solve the stress evaluation problem using sEMG as the study object. The stressinducing stimulation, analysis, and evaluation system with the problem of individual differences were established. This study proposed an improved SVM classification assessment algorithm by classifying after clustering, to solve the individual difference problem during evaluation of stress/non-stress reactions automatically and giving the clustering results to SVM loss function, to improve the quality of classification evaluation.

Experimental results showed that the accuracy of stress evaluation classification based on SVM was $68 \%$, which was noticeably lower than the accuracy of the improved algorithm (79\%). Thus, the improved algorithm showed higher classification accuracy 
for stress evaluation with individual differences. The improved algorithm could decrease the stress evaluation time by selecting training samples. The classification time was decreased from 2026.5 to $541.3 \mathrm{sec}$ after the improvement. The improved SVM algorithm can address the effects of individual differences during the stress state assessment.

Acknowledgement. This work was supported by the funding project for outstanding experts go abroad in the Hebei province and the key project in department of education of the Hebei province.

All participants were informed about the experimental process and subsequently signed and provided the informed consent. The ethical protocol of this study was based on the Declaration of Helsinki and existing international ethical standards.

The authors, L. Xin, Ch. Zetao, Zh.Yunpeng, X. Jiali, W. Shuicai, and Z. Yanjun, confirm that there were no conflicts of any kind relating to commercial or financial relations, relations with organizations or persons, which could in any way be associated with the investigation, and with the relationship of the co-authors of the article.

\author{
Л. Ксін ${ }^{1,2,3}$, Ч. Зетао ${ }^{1,2}$, Ж. Юнпен ${ }^{1,2}$, Кс. Джіалі ${ }^{1,2}$, \\ B. Шуїкай ${ }^{3}$ 3. Янчжун
}

\section{ОЦІНКА СТРЕСОВОГО СТАНУ ЗА ДОПОМОГОЮ ПОКРАЩЕНОГО МЕТОДУ ОПОРНИХ ВЕКТОРІВ}

\footnotetext{
${ }^{1}$ Інститут біомедичного інженірінгу Університету Яншань, Циньхуанда́о (Китай).

${ }^{2}$ Ключова лабораторія технології вимірювань та інструментів провінції Хебей, Циньхуанда́о (Китай). ${ }^{3}$ Коледж наук про життя та біоінженірінгу Пекінського технологічного університету (Китай).

Р е 3 ю м е
}

Ефективні методи визначення ступеня психологічного тиску можуть забезпечувати виявлення та оцінку стресових станів у реальному часі, примушуючи людей приділяти необхідну увагу їх здоров'ю. Метою нашого дослідження було оцінити стан стресу з використанням покращеного методу опорних векторів (SVM), базуючись на відведенні поверхневих електроміограм. Після того, як зразки даних були кластеризовані, результати передавалися до функції розділення SVM для того, щоб представити тренувальні зразки. Після встановлення дисбалансу між тренувальними зразками після скринінга для функції розділення надавався параметр ваги для зменшення тенденційності прогнозування класифікатора i, таким чином, зменшення похибки тренувального зразка і впливу незбалансованих зразків. Це покращувало алгоритм, підвищувало точність класифікації від 73.79 до 81.38 \% та зменшувало час обробки від 1973.1 до 540.2 с. Результати експериментів показали, що даний алгоритм може допомогти ефективно уникнути впливу індивідуальних відмінностей на оцінювання стресу та зменшити складність комп'ютерних розрахунків у перебігу тренувальної фази діяльності класифікатора.

\section{REFERENCES}

1. S. J. Lupien, F. Maheu, M. Tu, et al., "The effects of stress and stress hormones on human cognition: Implications for the field of brain and cognition," Brain Cognit., 65, No. 3, 209237 (2007).

2. D. Giakoumis, D. Tzovaras, and G. Hassapis, "Subjectdependent biosignal features for increased accuracy in psychological stress detection," Human comp. studies, 71, No. 4, 425-439 (2013).

3. R. Fernandez and R. W. Picard, "Modeling drivers' speech under stress," Speech Commun., 40,145-159 (2003).

4. J. A. Healey and R. W. Picard, "Detecting stress during real-world driving tasks using physiological sensors," IEEE Transact. Intel. Transport. Syst., 6, No. 2, 156-166 (2005).

5. W. Johannes, Augsburg Biosignal Toolbox (AuBT). User Guide. [http://emotion-research.net/].

6. G. Tartarisco, G. Baldus, D. Corda, et al., "Personal health system architecture for stress monitoring and support to clinical decisions," Comp. Commun., 35, No. 11, 1296-1305 (2012).

7. J. Hernandez, R. R. Morris, and R. W. Picard, "Call center stress recognition with person-specific models," Affect. Comput. Intel. Interact., Part 1, 125-134 (2011).

8. N. Sharma and T. Gedeon, "Objective measures, sensors and computational techniques for stress recognition and classification: a survey," Comput. Methods Progr. Biomed., 108, No. 3, 1287-1301 (2012).

9. S. Cheng, Q. Mo, and H. He, "Effects of office noise on staff health," J. Envir. Health, 17, 154-155 (2000).

10. H. Jahncke, S. Hygge, N. Halin, et al., "Open-plan office noise: cognitive performance and restoration," J. Envir. Psychol., 31, No. 4, 373-382 (2011).

11. http://www. sound $101 . \mathrm{com} /$.

12. A. Hogh, A. M. Hansen, E. G. Mikkelsen, and R. Persson, "Exposure to negative acts at work, psychological stress reactions and physiological stress response," J. Psychosom. Res., 73, No. 1, 47-52 (2012).

13. V. N. Vapnik, The Nature of Statistical Learning Theory. Second Ed., Spinger Verlag, NewYork (2000).

14. O. L. Mangasarian and D. R. Musicant, "Successive overrelaxation for support vector machines," IEEE Trans. Neural Netw., 10, No. 5, 1032-1037 (1999).

15. X. Li, Y. Wang, J. Song, and J. Shan, "Research on classification method of combining support vector machine and genetic algorithm for motor imagery EEG," J. Computation. Inform. Syst., 17, No. 12, 4351-4358 (2011). 